This is a pre-publication version of the chapter appearing in Mariko Hori Tanaka, Yoshiki Tajiri and Michiko Tsushima (eds), Samuel Beckett and Pain, Editions Rodopi 2012 (Faux titre 372)

\title{
Beckettian Pain, In the Flesh: Singularity, Community and "the Work"
}

\author{
Garin Dowd
}

\begin{abstract}
This essay argues that the representation of pain in Beckett's writing exposes the paradox in his work concerning the relationship of the individual suffering subject and the community. Making reference to studies of pain and literature generally and to salient studies of Beckett, the essay shows how the narration of pain in Beckett's prose works in particular is closely linked to its more general interrogation of subject-object relations. As the preeminent agent, source as well as repository of pain, writing in Beckett itself comes to occupy, in a transpositional manner, the poles of subject, object and work. If 'pain' names the subject-object continuum (and thus a community of subject and object), that very conjunction exposes the co-habitants to their own mutual espacement - qua subject and object. The common feeling (of pain, of pains at each of the poles) is countermanded in advance by separation. The conjunction gives rise to a sapping, devastating and agonising attempt to conjure an image (of and as the object), an image which holds out the possibility of the felicity, or at least palliation, offered by community (and the work). The image is, however, both a wounding regime (which impedes utterance) and a generative regime (in that the thwarting of utterance restores the compulsion to continue to attempt to conjure the image through writing). The two components, pain and community, are illustrated with specific reference to Texts for Nothing, through an analysis of which a new conjuncture of the themes of pain, community and the role of the work of art is proposed.
\end{abstract}

But whom can I have offended so grievously, to be punished in this inexplicable way, all is inexplicable, space and time, false and inexplicable, suffering and tears, and even the old convulsive cry.

Texts for Nothing

...here it's pure ache...

Texts for Nothing

The response of Beckett commentators to representations of physical and psychological pain in his work has inevitably been coloured by more general trends in the critical literature. From the universal suffering identified by early "humanist" critics, to those who came subsequently to invoke Foucault's theorisations of the disciplined body or of pain as "constructed," to the fruitful engagement by commentators with the enormously influential account of "the body in pain" undertaken by Elaine Scarry, to responses couched in the vocabulary of the Kantian sublime (for example Myskja), to the accounts, now becoming more prevalent due to the wider availability of until now relatively inaccessible archive materials, of Beckett's own experience of physical and psychological suffering and his attempts to deploy these experiences (as well as his analysis with Bion) in his own writing, pain has always been on the horizon. In this context it is worth citing the recent assessment by Eric Levy that the construal of pain in commentaries on Beckett reveals much about hermeneutic dispositions in the field. Noting the tendency to abstraction, in its various forms (comprising both approaches independent of and informed by post-structuralism), Levy suggests that "the critical emphasis on abstraction collides with the recurrent textual emphasis on pain" (21). On this account a certain tendency in the critical literature is at odds with the concrete exposition of pain in the writing itself.

Some of the most notable accounts of the representation of pain have located Beckett's concern with it in the context of religion and in particular with Beckett's Protestant heritage. Others have situated the question of pain in the context of a more metaphorical suffering of the unavoidable demands of expression to which the entirety of his work can be said to bear witness. In terms of critical responses to these issues, there have also been studies of specific works by 
Beckett which concern themselves with torture in particular. The present study seeks to add to these accounts; it draws on them, but aims to extend the account of pain in Beckett with reference to its connection to the theme of community. Texts for Nothing will form the principal reference point for the discussion in the second part of the study.

\section{The Body in Pain: Singular Suffering and Collective Expression}

The question of pain often arises in a context in which ideas of individuality and community are invoked, explicitly or implicitly. One of the most frequent iterations of this conjunction arises in the notion that in Beckett's work one encounters an expression of universal human suffering. ${ }^{1}$ Just as Beckett's work has been a privileged location for the exploration of these broader debates concerning identity, power, violence and authority as they manifest themselves in a literary context, so also it has been singled out for the specific nature of its intervention in the twentieth century. At the Tavistock lecture which the author attended in the company of his analyst Wilfrid Bion in 1935, Carl Jung makes a correlation between physical and psychic pain which no doubt influenced Beckett. He also makes some comments about pain in relation to the theme of community. In pursuing an argument about the role of archetypes in the collective unconscious, Jung asserts that "if the archetypal situation underlying the illness can be expressed in the right way the patient is cured" (116). By contrast, if no adequate expression for the archetypal situation can be found the individual is said to be "thrown back upon himself" (116). In the case of psychological suffering there is necessarily a severance of the individual from common humanity. If however, especially in retrospect, following the alleviation of suffering, its abeyance or cessation, the individual can associate his or her individual suffering with a common suffering then the individual will find him or herself elevated out of his/her solitude and connected with humanity. Healing both physical and psychic, in Jung's formulation, derives directly from a combination of sympathetic relation, being-with and company (albeit necessarily retrospective). In her hugely influential (not least in the area of Beckett studies) study of the body in pain in literature Elaine Scarry in fact articulates the relationship between pain and expression in terms highly redolent of these Jungian formulations. Scarry identifies an aspect of pain which will be central to any understanding of the question of the topic in conjunction with that of community: "physical pain is exceptional in the whole fabric of psychic, somatic, and perceptual states for being the only one that has no object" (161). Pain effectively produces a force of severance from community and collective belonging. Pain isolates its sufferer. In not possessing an object in the external world, pain is not of anything-it is, as she puts it, itself alone (162). As far as the topic of the present essay is concerned, Scarry's elaboration of a framework within which can be mapped all of human activity entails her positing pain at one extreme and another essentially isolating experience at the other: imagining. It is hardly surprising, then, that Beckett scholars have been so indebted to her work, with its compelling-as far as they are concerned-conjunction of two such "Beckettian" polarities-even if, or perhaps especially if, in the case of Beckett's work, the sense of any opposition of the two is swiftly challenged.

In a key respect, however, the experiment of imagining (which phrase I use in order to connect later with what Giorgio Agamben has called the experimentum linguae) is not solitary and does not isolate its agent, and for this reason it is located at the opposite pole from pain in Scarry's formulation. Whereas the experience of pain is a "pure" experience without object as such, by contrast the imagination is the only state entirely made up of objects (162). The contrast serves to point up a key aspect of pain and its sufferer's sense of location. Exposed to pain's power to sever from the world of objects, the sufferer is lost to spatial reference points. Whereas in the act of

\footnotetext{
${ }^{1}$ Though, as Levy argues, this is already a reading compromised by the paradoxical possibility, opened by Beckett's treatment of what is in effect a dictum handed down from Aquinas: thus the sin of having been born can be construed as referring to either a universal condition or a unique one - the ambiguity is intractable (Levy 33).
} 
imagining, by contrast, "[t]he activity producing the object tends to be coterminous with and only knowable through that object" (164). Of course, pain, while it presents challenges to discourse in that it destroys language, can become "intentional" in Scarry's sense, but it only becomes so "once it is brought into relation with the objectifying power of the imagination" (164). This is the case with sadomasochism, of which Beckett's oeuvre offers a few notable examples (How It Is, for example), or relationships open to being read within the context of sadomasochistic economies of pleasure and pain. ${ }^{2}$ The example of sadomasochism, where the sadist derives pleasure from inflicting pain and the masochist experiences pain as a necessary precondition to pleasure, however, is merely one highly schematic example of the more general principle whereby "pain and imagining are the "framing events" within whose boundaries all other perceptual, somatic, and emotional events occur; thus, between the two extremes may be mapped the whole terrain of the human psyche" (165). Scarry's reading of the body in pain in literature offers an opportunity to reflect on critical responses by Beckett scholars to the value one might attribute to the representation of pain in his work. In particular she posits a redemptive role for literature which one could envisage being harnessed to defend the work against the charge of nihilism, an aspect of her theory to which we will return in our conclusion. ${ }^{3}$

A further potentially important contribution to our understanding of representations of pain in literature is proposed in Steven Bruhn's book Gothic Bodies: The Politics of Pain in Romantic Fiction. In Bruhn's reading, for the Marquis de Sade (whose work Beckett read and considered translating) pain is the most aesthetic experience we can have (5). On the other side of the Enlightenment from Kant, then, aesthetic experience entails a validation of physical sentience and the strongest experience of this is pain (5-6). ${ }^{4}$ However, by virtue of this strength pain threatens the very aesthetic continuum of which it is a part (6). Pains have names; they have discourse attached to them, despite the capacity of painful sensation to wrench the subject out of its relational frameworks; according to Bruhn, physical pain is to a significant degree mediated by the sufferer's culturally determined understanding of pain (8). In the experience of physical pain there is a mixture of noiception (physical) and perception (mental). If pain inflicts damage on the self, it is not able to activate a centrifugal force which would compensate through the common.

One of the conjunctions germane to this discussion which Beckett's work explores is sympathetic pain, either in its presence or absence of sympathy, one of the figures of communing via projection-a relation with the other, however, also produces a countermanding force. As Bruhn states: "If sympathetic pain presses too close it evokes desire for self-preservation which destroys community" (qtd. in Burke 17). There occurs then a legitimation crisis for a notion of community based on sympathy (27). Pain serves to isolate the sufferer from all others. In this way, pain "destroys Cartesian individualism only to end up re-inscribing it" (27). This formulation succinctly describes a paradox pervasive in Beckett's writing, as exemplified in The Unnamable where "they want me to have a mind where it is known once and for all that I have a pain in the neck" (324). The Lost Ones may be read in this context as a reflection on the situation where there is no sympathetic relation, or where sympathetic relation is impossible. In his chapter on "The Mimesis of Pain," Eric Levy cites in this context Malone Dies: "The wound ultimately concerns the need to persist in registering pain, and the pain ultimately concerns the persistence of futility: I give rein to my pains, my impotence" (210; qtd. in Levy 13). The wound is open and

\footnotetext{
${ }^{2}$ For Gilles Deleuze, "In sadism no less than in masochism, there is no direct relation to pain: pain should be regarded as an effect only" (121). The sadomasochistic economy comes to place repetition--as well as waiting and anticipation conditioned by repetition--as the force presiding, rather than pain. Repetition establishes a rhythm of desexualization (of Eros), as Deleuze puts it, and resexualisation (of Thanatos).

${ }^{3}$ As a qualifying comment it should perhaps be noted, as Shane Weller reminds us, the charge of nihilism is notable for the surprisingly few times it has in fact been made against Beckett.

${ }^{4}$ In his preface to his study of Sade Pierre Klossowski writes "if the sovereignty of man is the principle and the goal of rational atheism, Sade, liquidating the norms of reason, pursues the disintegration of man" (Klossowski 5).
} 
in this way is a protection against more suffering; suffering as revenge against suffering. ${ }^{5}$

\section{Nature, Community, Suffering}

Pain, understood in the context of public suffering and the exposition of the suffering body, has been linked by Beckett scholars to the historical origins of theatre, and in particular to the sacrificial context of Greek tragedy. Thomas Cousineau has suggested that Waiting for Godot plays with the distribution of individual and community as it is expressed in Greek tragedy. In the dismantling of the apparatus of tragedy in its Sophoclean form one no longer attends to a divided community represented on stage and comprising the innocent community and its guilty scapegoat or sacrificial victim. The dismantling of these coordinates which Godot represents entails the provisional identity of Lucky as a bouc émissaire performing his Scapegoat's Agony, but he also forms a kind of community with the other three central characters, who themselves all take on intermittently the role of the scapegoat. In this context, the community does not expiate successfully, but can only displace and transfer the suffering. This extends in Beckett's conception, as described by Cousineau, to the audience which must also shoulder its share of the suffering by being refused its traditional immunity (227). In this sense, Godot is anti-sacrificial.

As the transitory bouc émissaire for a dismantled structure of scapegoated agony who experiences a rudimentary community within the shadow of a bare tree, Lucky suffers. ${ }^{6}$ The play distributes the suffering. The suffering is shared. This is post-sacrificial suffering. In this context, Tyrus Miller's essay on the function of torture in the late drama is a vivid account both of the trope and of the previous reflection on the theme. Referring to the tradition of "[s]elf-tormenting lyric subjectivity" (257-258) with which the work of Beckett has so often and too hastily been associated, Miller offers some alternatives. In Adorno he finds the possibility of another reading of suffering within the context of Adorno's conception of art after Auschwitz. "Expression is the suffering countenance of artworks" (Adorno qtd. in Miller 260). In such a context (that of the unpresentable) abstraction, within the figuration of suffering, becomes a protest against suffering (261). ${ }^{7}$ If, as Adorno argues, expression represents a kind of figural trace of extra-aesthetic pain as mediated through the material of an artistic language, Beckett re-marks this figurality of artistic expression with the literal presence of bodies in pain and their "expressions" (261). Thus, in Miller's account, pain is there as if diacritical markings acting on the words.

The fate of all the characters in Waiting for Godot or Endgame is not so much suffering as it is that which, in different contexts, Jean-Luc Nancy, Giorgio Agamben and Michael Hardt have described, in their (broadly) related accounts of the post-sacrificial world of Western society in the aftermath of World War II, as exposure. Before any consideration of exposure in the specific contexts of these thinkers, however, it should be noted that Beckett's own interest in the theme of exposure is very evident. In one of his key resources, Shakespeare, the state of being exposed describes the turmoil in which we find Lear on the heath, without shelter, divested of the power and responsibility of the throne. ${ }^{8}$ The body here is the body in part returned to the state of nature,

\footnotetext{
${ }^{5}$ To a certain extent there is a point of convergence between Beckett and Céline, an author whom we know Beckett admired. In Julia Kristeva's chapter "Suffering and Horror" the subject for Céline begins in suffering, and a "primal narcissistic wound" shatters narrative (155).

${ }^{6}$ Commentators have often noted that in his Tavistock lectures Jung refers to the two thieves between whom Christ was crucified, noting that they too had participated in the redemption of humankind as scapegoats (109).

${ }^{7}$ In what amounts to a challenge to certain orthodoxies in Beckett commentary, Weller alerts us to the fact that an entire critical tradition since Adorno has valorised an "openness or a resistance to complete self-embracement, with the work being seen as governed by an ethic of hospitality to the radically other" (147). The Beckettian community, in his account, which is an unavowable one--in Blanchot's sense--is built on pain, or is constructed in order to avoid suffering. It does not, à la Adorno, reveal the open wound of the unpresentable, the horror which cannot be represented; it is not an inscription of this unrepresentable suffering (in this sense Weller does not accord with Tyrus Miller's account).

${ }^{8}$ Kantorowicz's concept of the two bodies of the King is a key reference point here.
} 
with the temporary suspension of the Leviathan which in Hobbes' view rules over human actions. With Edgar on the heath the hovel of which he has been informed by Kent (III ii, 60), is approached and gives rise to Lear's description of the exposed and scattered community:

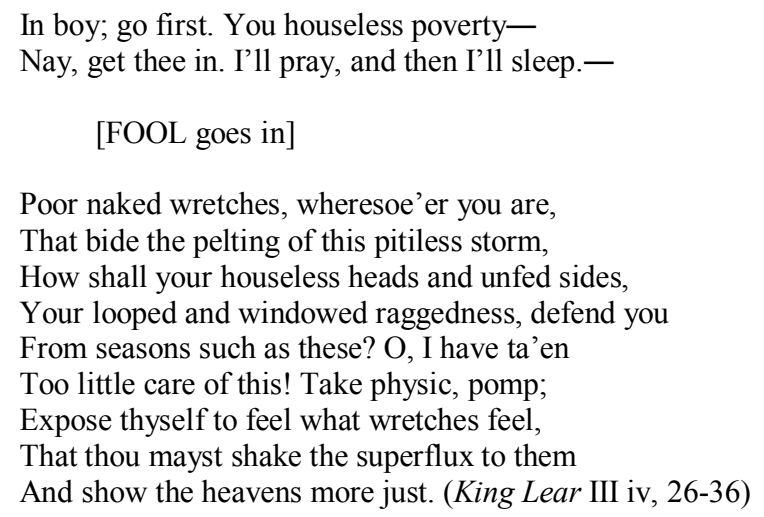

Lear's words are of course echoed in Beckett's phrase in Texts for Nothing (but also reformulated elsewhere): "untenanted is." 9 The structure, however, by virtue of Lear's analogy, is the body. A lack of shelter or dwelling is the essence of the human exposed and compromised:

Why wert thou better in thy grave than to answer with thy uncovered body this extremity of the skies. Is man no more than this? Consider him well. Thou owest the worm no silk, the beast no hide, the sheep no wool, the cat no perfume. Ha! . . Thou art the thing itself; unaccommodated man is no more but such a poor, bare, forked animal as thou art. Off. Off you lendings! Come, unbutton here. [III iv, 96-103]

Having surveyed the scattered (in their "houseless poverty") and identified with the exposure they suffer and with which they coincide-their essence is to be exposed-Lear abandons his own carapace. As Linda Ben-Zvi has pointed out, the key difference between the exposure which Beckett's characters suffer and Lear's is that they come into the world already exposed (2), whereas the subjects of Shakespeare's tragedies experience a fall into exposure-and nowhere more emphatically than in King Lear.

In this context, Giorgio Agamben elsewhere elaborates on the theme of the bare life which is the state of exception, the annihilable other legitimately to be sacrificed with impunity. Recent studies, notably by David Houston Jones, have been devoted, quite properly, to exploring the possible points of contact between Beckett and Agamben. In King Lear, bare life on the heath, among the people in one sense of the term, is such a state of exception; the state inhering in the monarch momentarily going thence to the other side, the place of the bare, forked animal.

\section{Waiting, Pain, Exception, Sacrifice}

When considering the theme of pain, Beckett commentary has often turned to the iconography and theology of Christianity, with three key sources in the case of Beckett being Scripture, Protestant conceptions of the body, and of course Dante's Divine Comedy, and in particular the Inferno and the Purgatorio. In her book Samuel Beckett and the Idea of God, Mary Bryden (in a chapter entitled "Rats, Crosses, Pain") develops a meticulously supported argument regarding the location of the idea of pain in Beckett's work in the joint contexts of Scripture, Christianity and Dante. In particular, considering the typology of Beckettian postures, the importance to Beckett of the figuration of the crucifixion, in writing, belief and artistic expression cannot be

\footnotetext{
${ }^{9}$ Of course, critics have made much of the links between Shakespeare and Beckett, King Lear and Hamlet in particular being discernible in both individual phrases ('Astride of a grave and difficult birth' being traceable to King Lear IV.vi. 178-180; 182-183, for example.). See Sullivan.
} 
overestimated. ${ }^{10}$ However, she cautions us that "the simplicity of the crucifixion image is often embedded in a web of connotation, revealing the author's familiarity with the entirety of the Passion narratives, and not just their culminatory point" (146). The crucifixion is for Beckett merely the finale of the Passion. So it is that the punishment and suffering on the cross-of course also frequently evoked in Beckett's writings-are part of another taxonomy in Beckett-that of waiting. As Bryden reminds us in this connection (149), the narrator in Comment c'est at one point waits for pain in order to find guarantee of his continuing existence:

Prendre le sac dans mes bras l'amener si léger tout contre moi y coucher ma joue c'est la grande scène du sac elle est faite je l'ai derrière moi la journée est bien avancée fermer les yeux enfin et attendre ma douleur qu'avec elle je puisse durer un peu encore et en attendant. (55)

Beckett subjects Christian notions such as offering up sufferings in order to atone for sin, and suffering torment as a universal punishment for man's sins against God in consigning his son to death, to parodic reinscription in environments and situations which have been stripped of the clear coordinates and chronology of the Passion and its narratives. ${ }^{11}$ The same divestment of motivation occurs in the use to which Dante is put. Within the latter "every punishment [and].physical assault has 'meaning' within the psyche of the recipient" but, the same is not true in Beckett (157). There is no justification for, or explanation of, pain and suffering in Beckett's writing; as Bryden puts it: "the primary experience is of unfathomable, meaningless suffering: the 'damnation obscure' of which the narrator speaks in L'Innommable" (L'Innommable 36; qtd. in Bryden 57).

The obscure damnation involves a body in varying degrees of conjunctive and disjunctive relation with a voice. The suffering subject is condemned to utter, and suffers from not being able to utter. The modality of suffering is either ante-purgatorial (when it is aligned with Belacqua) or to be found shuttling across the threshold between the purgatorial and the infernal. When this obscure fate is not explicitly Dantean it is often evoked in relation to the Christian theme of incarnation.

Beckett criticism has not surprisingly been finely attuned to the author's interest in the theme. Bryden has referred in particular to the idea of kenosis:

Rather than being blurred with the Father, in a triumphalist Godhead, Christ is overwhelmingly discerned in kenotic mode: emptied, made destitute, and available for suffering of the worst kind. $(140)^{12}$

Other Beckett commentators have identified other texts as imbued with crucifixion tropes. As Derval Tubridy observes in her study of incarnation and Beckett, "The body which speaks in How It Is does not so much produce speech as suffer it" (101); "In order for the word to be made flesh and to be spoken through the body, the integrity of the body must be destroyed through pain and wounding. And from these wounds comes speech" (101). "Incarnation ratée", as Grossman specifies (60), the failure "d'un sujet dans un corps de langue" (61).

Michael Hardt has, in the course of a reading of the Italian film director Pier Paulo Pasolini's approach to the crucifixion, amplified some of Agamben's insights on the concept of the flesh which will prove useful to our consideration of the exposure of the flesh in Beckett. ${ }^{13}$ Hardt

\footnotetext{
${ }^{10}$ See also Grossman 110-116 and Rabaté 156.

11 "Ooftish" is, according to Bryden, a parody of "the doctrine that sufferings can be 'offered up', and united with Christ's sacrifice, for the sake of purification or remission of the punishment due to sin" (148).

${ }^{12}$ Eric Levy, who seems to be unaware of this work in his account of kenosis on pages 95-98 of his study, nonetheless agrees that the employment of the doctrine in Beckett (deriving from 2 Corinth 8.9) is scatalogical (as in the term "wordshit" in Texts for Nothing) not Christian (Levy 98).

${ }^{13}$ Pasolini's main film in this regard is The Gospel According to St. Matthew (1964).
} 
begins his short essay by glossing the words of Paul on the abandonment which is entailed in the incarnation of Christ. In incarnation, Hardt argues, the form of God is abandoned, via a selfemptying. ${ }^{14}$ Locating three propositions - a metaphysical, theological and ethical proposition respectively-the strange news that Pasolini hears, from, as Hardt puts it, the "impure angel" of the crucifixion, is that, through this self-emptying, rather than the confirmation, via correspondence and conformity, of the form of God, one is left with "merely a hollow husk." Paradoxically, "The self-emptying or kenosis of Christ, the evacuation of the transcendental, is the affirmation of the plenitude of the material, the fullness of the flesh" (78), and an absence of mediation. Instead incarnation heralds the "intimate complementarity" of transcendence and the immanent (79). In this way, then, "[t]he surfaces of the world are charged with a powerful intensity. Divinity resides precisely in the boundaries of things, at their limits, passionate and exposed, as if surrounding them with a halo" (79). This is the theological proposition: as a result of incarnation there is no hidden God. Equally, however, there is no one God: rather there is a disseminated divinity. The ethical dimension in Pasolini's response to this phenomenon (as glossed by Hardt in a distinctly Deleuzean register) comes in the form of the pedagogy of this world and this world alone, that is: believe in this world. As such this amounts to an atheistic position, albeit one arrived at through the logic of the incarnation.

What Pasolini focuses upon in the crucifixion is the "immodesty" of the sacrifice. The husk having been abandoned (that of course is not in itself enough to generate a deus absconditus), and the flesh having been joined with an "erotic" continuum (what Beckett in How It Is calls the vast imbrication of flesh without breach or fissure), crucifixion is the culmination of incarnation. ${ }^{15}$ But it takes the form of an exposure: "Christ is all body, an open piece of flesh, abandoned, exposed" (as, one might venture, in a painting by Francis Bacon). "Exposure, then, does not recreate the scene of torture but rather seeks to dissolve its boundaries and its effects of discontinuity" (82). In this context:

Flesh certainly refers to matter, a passionately charged, intense matter, but it is always equally intellectual. It is not opposed to or excluded from thought or consciousness. Rather, the paths of thought and existence are all traced on the flesh. Flesh subtends existence; it is its very potentiality. (82)

The reading performed by Hardt is not only deeply influenced by Agamben (Hardt is after all the translator of The Coming Community), it is in fact dedicated to him. It is no surprise, then, to find the key Agamben concept of exposure at the core of the analysis and the argument underpinned by Agamben's approach, undertaken, via his reading of Aristotle, of potential, and in particular, in a formulation close to Beckettian language, the potential not to be.

This figure has obvious affinities with Beckettian negation ("It was raining. It was not raining"), but equally the idea of exposure in the flesh is something frequently found in Beckett's oeuvre. The prone Belacqua of "A Wet Night," Murphy's naked masochistic self-bondage, the exposed bodies in the asylum grounds of Watt, the procession of How It Is, the naked bodies of The Lost Ones climbing their ladders, these figures intermittently evoke tropes of Christ's passion-albeit usually invoked for parodic purposes-but more crucially they are evidence of Beckett's enduring interest in incarnation as exposure. ${ }^{16}$ Underneath the community of bodies lies the continuum of flesh-including the idea of flesh engendering flesh, or reproduction, birth, death and decay.

\footnotetext{
${ }^{14}$ Many Beckett scholars have commented on kenosis. See for example Bryden and Barry.

${ }^{15}$ Cf. Caselli 158.

${ }^{16}$ See Caselli's study of Beckett's Dantes.
} 


\section{Agony and Language}

The discussion can be taken further by returning to the scapegoat. As Andrew Gibson has pointed out, Lucky's monologue is littered with references to wartime politics of the Vichy regime, to collaboration and to wartime displacement, forced movement and deprivations. Heidegger's own philosophical engagement with the metaphor of homelessness (in Letter on Humanism, "Building, Dwelling, Thinking" and "The Question Concerning Technology") not only subsumes the actual plight of the "unaccommodated man" of the post-war period, it also effaces the specific genocide ultimately perpetrated by the regime under which Heidegger himself flourished in the 1930s in favour of a universality cleansed of grim historical specificity. ${ }^{17}$ Beckett, by contrast, was in part adrift in the displacement occasioned by the historical force of National Socialism with which Heidegger had colluded in the 1930 s. ${ }^{18}$ Faced with a phenomenon which each in his way attempted to accommodate, the one to literature, the other to philosophy for their respective disciplines, language adopts quite distinct roles, roles which reveal politically, philosophically and historically divergent and antagonistic approaches to human suffering.

In a short text in The Coming Community, Agamben writes of the figure translated into English as "whatever" that it is the figure of pure singularity. Singularity, in Agamben's formulation, borders all possibility; the singularity receives its determination not from participation in some determinate concept but only by means of this bordering. There is only the relation to an empty and indeterminate totality. This bordering is not a question of limit but of threshold: "that is, a point of contact with an external space that must remain empty" (67). A threshold is an added emptiness: thus "whatever" may be understood as singularity plus an empty space. The singularity is finite but indeterminate according to a concept. The combination singularity + empty place is equivalent to pure exteriority or exposure. Thus "whatever" is the event of an outside. For Agamben, Outside is not another space outside determinate space but the passage. The threshold is thus the experience of the limit itself: "the experience of being-within an outside. This ek-stasis is the gift that singularity gathers from the empty hands of humanity" (68).

The Aristotelian definition of potentiality, upon which Agamben bases the above, means that potentiality embraces the possibility of not-being, of not to be. This is the potentiality that cannot pass into actuality. The passing over into actuality only occurs when the potential not-to-be is left behind: "An act is sovereign when it realises itself by simply taking away its own potentiality not to be, letting itself be, giving itself to itself" (46). In the appendix to The Coming Community Agamben renders explicit the Heideggerian framework for some of the material outlined above. Drawing on Heidegger, Agamben proposes the concept of "thus," which he equates with "not otherwise," an anaphora "that no longer refers back to any meaning or any referent, an absolute this that does not presuppose anything, that is completely exposed" (94). Thus would be the singularity: no essence upon which the singularity can depend, or upon which it is founded, which is why the state and the singularity are anathema to each other. However, when translated into what Agamben calls the experimentum linguae, considered here in the extrapolated context of Beckett's work, we are in the presence of what he calls the "decisive event of matter, and in doing so opens us onto an ethics" (Potentialities 219). Agamben couches his reply to Jean-Luc Nancy and Maurice Blanchot on the question of community in terms of the commonality of the human's experience of language's materiality: "only because man finds himself cast into language without the vehicle of a voice, and only because the experimentum linguae lures him, grammarless, into that void and that aphonia, do an ethos and a community of any kind become possible," he writes in Infancy and History (9). The task for humanity is to participate in an essentially unpresupposable belonging; therein for Agamben lies the potentiality of the coming

\footnotetext{
${ }^{17}$ See Agamben on the correlation of National Socialism's production of bare life and Heidegger's thought.

${ }^{18}$ Jean-Luc Nancy points out the fascistic associations of the word 'community'.
} 
community.

Beckett frequently connects the conjunction of the themes of pain and community to questions of habitation, understood both materially and metaphorically (underpinned by the injunction to imagine). His writing, in both its the-place-which-says and saying-the-place (to translate Janvier) modalities, adheres to the double register of King Lear on the heath. Some of these preliminary insights will now be explored in relation to Texts for Nothing.

\section{From Imagining to Work: Texts for Nothing}

In his important study of Beckett and community, Shane Weller points out how the impossible community is not simply founded on absence but on the presence of absence, and he singles out Texts for Nothing in this regard (153). Texts for Nothing will now be read in close conjunction with the tripartite division which I have extracted from the critical commentary on Beckett: the specific case of crucifixion; purgatorial and infernal suffering. Let us consider first the presence of the crucifixion-incarnation nexus. The text evokes the startling presence of "a carcass in God's image." This remarkable evocation of kenosis arises at the station (suggesting albeit fleetingly, a station of the cross) which should be, we are told, struck from the name of places to visit. The phrase is of course a corruption of Genesis ("Let us make man in our image": Genesis 1.26ff). The mimesis of the Divine being is a cadaver. Born astride a grave is one of the Beckettian refrains for the trauma of being born (Jung's Tavistock lectures). From generalised cadavricité to specific embodiment, from Eden to Calvary, one garden to another (as across the fence in Watt), the carcass is also that of Christ as exposed, tortured, executed representative of God on earth. Incarnation is already incarnation ratée (Grossman 60). Incarnation also is the forging of identity on the body which will be any body, a singularity, unless given coordinates (place of birth, date of birth), formation, dwelling, address. The failure of these to resolve the body leads to the failure of adherence evoked in the conclusion: "this lump is no longer me" (129). This meditation on the failed resolution or botched incarnation is preceded by a consideration of the theme of the trinity: "this other without number or person whose abandoned being we haunt, nothing. There's a pretty three in one, and what a one, what a no one."

In terms of Dantean pain and community, purgatory is directly invoked in the shape of the frozen figures (124-125). Damnation and divine judgement are implicated (125); there will ensue the following operations: "expiate, coming and going in passing time, every day a little purer, a little deader" (133). The text gestures in detail towards punishment and atonement by asking: "But whom can I have offended so grievously, to be punished in this inexplicable way, all is inexplicable, space and time, false and inexplicable, suffering and tears, and even the old convulsive cry" (133). The flesh here is already exposure: to be enfleshed is already a punishment ("committal to flesh"-142); there have never been anything but "expiring vitals" (150). This drama has an observer: "a god, unwitnessed witness of witnesses" (151).

The Texts for Nothing are remarkable for the recurrent attention to habitation, place, body and voice and to the interpenetration of these. Text 1 establishes its voice on what is described among other things, in an echo of King Lear (and Wuthering Heights), as a heath. The utterer finds himself exposed to the elements, or at least three of them. He has erred from his den: "All you had to do was stay at home. Home. They wanted me to go home. My dwelling-place" (101). "What possessed you to come? Unanswerable." The range of possibilities, as so often with Beckett, includes allusion to incarnation: "Yes, I was my father and I was my son" (103). Thus the place whence he comes may be construed as the (divine) life above, and his presence on earth the outcome of the divine Word projecting him into fleshly form.

The community is invoked in the phrase "my little company" (103); one of the voices from the past which echoes to him is a bedtime story about a son (of a lighthouse keeper) told by a father to a son. Yet the distinction between addressee and addresser, as between father and son, is blurred such that he asks himself the questions and in holding the hand of the other in fact holds his own. This relation of non-relation is posited as the key to survival: 
We walked together, hand in hand, silent, sunk in our worlds, each in his worlds, the hands forgotten in each other. That's how I've held out till now. And this evening again it seems to be working. I'm in my arms, I'm holding myself in my arms, without much tenderness, but faithfully, faithfully. Sleep now, as under that ancient lamp, all twined together, tired out with so much talking, so much listening, so much toil and play. (103-104)

But, even though the second text begins with an invocation of the "life above," we know that in Beckett these allusions are part of a panoply of competing narratives. Hence the habitability which is said to be challenged in Text 2 is at once habitability itself, shown to be challenging and arresting, and in this sense a station for Text 1, and on the other hand the habitability that is incarnation (both metaphorically and the text as incarnation). Whereas Text 1 offers the possibility of going back down, 2 suggests that one may ascend. The possibility is of course quickly undercut: "Back above? There are limits" (105). In a characteristically reduced field for inter-subjective relations, both Text 1 and Text 2 feature a community of observers: in 1 it is those who have inexplicably come to the heath to witness the exposure, while in 2 it is those deemed to be abroad, a rabble reserved for memory (107). But the overriding indication is contained in the phrases "here it's pure ache" (106) and "Utter, there's nothing else, utter, void yourself of them, here as always, nothing else." Pain and utterance are interwoven.

Text 3 posits departure as the next step. Departure would only commence once the rudiments are in place. These are, inter alia, a body capable of presence, location and uprightness (a theme later taken up emphatically in Worstward Ho). The battle will be with inextricable place; the sheer intransigence of place (by contrast, time is of little concern). Thus: "the bits and scraps, flickering on and off" (110); "to be bedded in that flesh or another" (113); "There is no flesh anywhere" (113).

Text 4 features the aporetic torment of a proximity which sets apart (the departure which is towards self but in this very departure which is the marker of the impossibility of return): "I wait for me afar for my story to begin, to end, and again this voice cannot be mine. That's where I'd go, if I could go, that's who I'd be, if I could be" (116).

Text 5 describes a judicial setting. It is the text most concerned with images, images coming to the eye through the lids, or conjured in the head. (119). At one point, the judgement pertains to divine judgement ("justice of him who is all love"). As Caselli argues, "Judiciary figures, as in Text 5, the witness and the scribe are part of the system of justice based on the endless 'moderate' martyrdom, caught between the impossibility of repetition (the possibility of fiction) and the construction of truth through repetition" (171).

Text 6 begins by asking how the intervals between the "apparitions" are filled. He wonders if they take rests before "setting about me afresh" (122). As so often in Beckett the bearer of the speaking voice-the as-if speaking voice-is located outside the community. He is being disciplined, punished or surveilled: "My keepers, why keepers, I'm in no danger of stirring an inch, ah I see, it's to make me think I'm a prisoner, frantic with corporeality, rearing to get out and away" (122-123). The text thus restates the problem of locomotion with which the collection Texts opens: going back, or going elsewhere. If there is no-one here, the refrain of the Texts, equally there is no-one elsewhere: "Elsewhere perhaps, by all means, elsewhere, what elsewhere can there be to this infinite here?" (123). The theme of departure in Text 7 is taken up with the rudiments posited in an earlier text now disarticulated again (the great theme of Worstward Ho in many respects): "far from that heap of flesh, rind, bones and bristles waiting to depart it knows not where" (129).

Text 8 posits a punished subject who, being forced to expiate some misdeed, asks: "But whom can I have offended so grievously, to be punished in this inexplicable way, all is inexplicable, space and time, false and inexplicable, suffering and tears, and even the old convulsive cry" (133). The one who suffers punishment, however, cannot (or will not) be defined as the one punished;. "It's not me, it can't be me. But am I in pain, whether it's me or not, frankly now, is 
there pain?" (133). The punishment delivered to the uttering subject is, in one particular sense of the word, 'unbearable', in that the pain inflicted cannot be suffered or registered in the subject which is the object of that pain. To be the bearer of the pain, to suffer it, one would need to hold one's position in the subject-object relation. To do so would moreover require utterance and the emission of words: "Watch out for the right moment, then not another word, is that the only way to have being and habitat?" (133). The text proceeds in its exposure of the oscillations and vacillations of the sufferer as it confuses the here of then and the then of there (139), and takes its distance from definition as an example of "what is called flesh and blood somewhere above in their gonorrhoeal light" (147). Finally the sufferer/utterer feels the pressure of a dictation without identifiable provenance, in the guise of unsheltered, deracinated and multiple voices in the hollow shell left by a deus absconditus: "this latest other, with his babble of homeless mes and untenanted hims, this other without number of person whose abandoned being we haunt, nothing. There's a pretty three in one, and what a one, what a no one. So, I'm supposed to say now, it's the moment, so that's the earth, these expiring vitals set aside for me which no sooner taken over would be set aside for another, many thanks, and here the laugh, the long silent guffaw of the knowing non-exister [...]." (150). The finale of this suffering/uttering arrives when nothing is made (153), precisely the "nothing' of Texts for Nothing.

The application of "no's knife" in "yes's wound" produces screaming silence; pain without an outlet, pain which must be suffered in silence not through mortification or masochistic subjugation, but as exposure. The murmurs continue, the inaudible, inscrutable, untranslatable, utterances of an unavowable community. It can't speak, it can't cease. This continuum, this babble:

And were there one day to be here, where there are no days, which is no place, born of the impossible voice the unmakeable being, and a gleam of light, still all would be silent and empty and dark, as a now, as soon now, when all will be ended, all said, it says, it murmurs. (154)

If the body in pain remains for Beckett a figure intimately caught up in the figure of Christ, so equally is it in the literature on sadism and masochism with which Beckett was very familiar. Just as Sade and Masoch, in Deleuze's account, staged their rituals in literature imbued with the social, cultural and political tenor of their times, so also does Beckett. In this sense, he is a physician of his times, a great symptomatologist. His exposure/expeausition, however, offers an alternative to a Heideggerian understanding of language as the house of Being. Beckett's language, as experimentum linguae in Agamben's sense, is diacritically marked by torment, pain and privation (Miller 261). In the flashes into visibility, the lamps turned on faces in interrogation, the scraps and fragments standing forth in glimpses of the late texts, in the overexposed whiteness of Imagination Dead imagine- "white speck lost in whiteness"; but see also the same sentence's storm and lost in blackness (185)-and the dim illumination of the naked bodies in The Lost Ones, Beckett posits the body as image, exposed, in the process of being exposed, emerging from blankness through gradations of grey. Emerging from the place and going to the place. Nothing more than exposure in the flesh. ${ }^{19}$

\section{Concluding Remarks}

Scarry's account of the place of the work (of literature) within the polarised framework of pain and imagination can assist us in drawing some conclusions regarding the conjunction of pain, work and community in Beckett's work. In her redemptive account of pain, work, the making of work, or the attempt to make a work, entails pain but, depending on the outcome of the attempt, it

19 Evelyne Grossman states of Beckett's late work that it "ne fait plus 'visage"”; "il se défigure, devient méconnaissable à mesure même que se déforme la vieille complicité du visible et du lisible, du signe et du sens" [it defigures, becomes unrecognizable even as it deforms the old complicity of the visible and the articulable, of sign and of meaning] (79). 
will occupy a different location in the space between pain and imagining: "the more it realizes and transforms itself in its object, the closer it is to the imagination, to art, to culture; the more it is unable to bring forth an object or, bringing it forth, is then cut off from its object, the more it approaches the condition of pain" (169). In work, and in particular in artistic work, one encounters an activity which combines both framing experience and experiment. There is, in Scarry's words, a sentence of a paragraph or a poem where there had been silence (171). If pain itself is contractive, the pain which resolves itself into work, as work, entails a movement out into the world. Thus for Scarry, the work initiates the possibility of sharing. Pain may come "unsharably into our midst as at once that which cannot be denied and that which cannot be confirmed" (4), but the work into which it can be transformed facilitates communication and the possibility of community. Likewise in Agamben, the work is thought according to a normative logic. While he is critical of any essentialist conception of the human, Agamben's normative conception of the work of art which requires that it be, as Claire Colebrook puts it, "world disclosive" (109), places constraints on what the "proper" work of art can be. Art, on this model, is a coming to humanity. "It is this coming to humanity that also aligns the work of art with speech, the praxis that constitutes the subject through its own action" (111). This is an essentially restorative experiment and experience in which, if we take into account the nexus of pain between subject and object (pain as relation of non-relation), privileges the work of art both as palliative and common bond. Agamben's singularity in this sense is the locus of imagination as making, praxis, doing, working and being-with. An alternative account of singularity is proposed by Gilles Deleuze in his Difference and Repetition and Logic of Sense. Deleuze proposes a theory of singularities understood in a framework developed out of a range of influences including Duns Scotus, Spinoza and Nietzsche. In the operation he calls "clothed repetition", what occurs is "the reprise of singularities by one another, the condensation of singularites into one another" (201) in an operation of universal ungrounding (202). Deleuze and Guattari's succinct assessment of the status of Molloy and Moran remains unrivalled in distilling the operation of transitions between subject and object, victim and tormentor, and the contending poles of individual and community in Beckett's work:

This is the meaning of the disjunctions where Beckett records his characters and the events that befall them: everything divides, but into itself [...]. The disjunction [...] will liberate a space where Molloy and Moran no longer designate persons, but singularities flocking from all sides, evanescent agents of production [...] all inhabited by a faceless and transpositional subject. (76-77)

Beckett's œuvre offers a relentless exploration of what it is to attempt to make a work. In doing so it repeatedly equates the experience of suffering and the experiment of utterance. Such utterance always takes place in the potential ambit of a work. The experiment can be said to be at its most pervasive in the Texts for Nothing, a work described by its author as an attempt to get beyond an impasse in his writing. The anguished expression concerning the inscrutability of pain in a group of texts which, taken together, seem to convene on the notion of a present absenceone which produces punishment, pain and suffering--is called Texts for Nothing. In many respects Beckett's . œuvre is an appropriate candidate for inclusion in Scarry's category of literary works adding to the sum of shared examination of pain and suffering. Through its complex association of the act of articulating in words and the process of physical gesture and posture in such a way as to problematise the very notion of a shared examination, however, one does not find in it the utopian opening which Scarry believes resides in the redemptive power of literature. Equally, it seems that, while the space between singularity and community which is the domain of Beckettian pain finds in Agamben much in the way of a welcome potential discursive gloss, the work which results does not warrant being employed to bear a normative account whether of singularity, community or the work of art. 


\section{Works Cited}

Adelman, Gary. "Torturer and Servant: Samuel Beckett's How it Is," Journal of Modern Literature 25.1 (2001): 81-90.

Agamben, Giorgio. The Coming Community. Trans. Michael Hardt. Minneapolis: Minnesota UP, 1993.

---. Homo Sacer: Sovereign Power and Bare Life. Trans. Daniel Heller-Roazen. Stanford: Stanford UP, 1998.

---. Potentialities: Collected Essays in Philosophy. Ed. and Trans. Daniel Heller-Roazen. Stanford: Stanford UP, 1999.

Barry, Elizabeth. "Faith cometh by hearing, and hearing by the word of God': the status of Beckett's religious language." Samuel Beckett Today / Aujourd'hui 9 (2000):173-184.

Beckett, Samuel. The Complete Short Prose 1929-1989, Ed. S.E. Gontarski. New York: Grove P, 1995.

---. Le Depeupleur. Paris: Minuit, 1972.

---. L'Innommable. Paris: Minuit, 1953. L'Innommable. Paris: Minuit, 1953.

---.Texts for Nothing. The Complete Short Prose 1929-1989. Ed. S.E. Gontarski. New York: Grove P, 1995.

---. Worstward Ho. London: Calder, 1993.

Ben-Zvi, Linda. Samuel Beckett. Boston: Twayne, 1986.

Blanchot, Maurice. Joë Bousquet (1948) par M. Blanchot suivi d'un essai de J. Bousquet sur Maurice Blanchot. Montpellier: Fata Morgana, 1987.

---, La Communautée inavouable. Paris: Minuit, 1996.

Bruhn, Steven. Gothic Bodies: The Politics of Pain in Romantic Fiction. Philadelphia: U of Pennsylvania P, 1994.

Bryden, Mary. Samuel Beckett and the Idea of God. Basingstoke: Macmillan, 1998.

Buci-Glucksmann. Tragique de l'ombre: Shakespeare et le maniérisme. Paris: Galilée, 1990.

Caselli, Daniela. Beckett's Dantes: Intertextuality in the Fiction and Criticism. Manchester: Manchester UP, 2005.

Colebrook, Claire. "Agamben: Aesthetics, Potentiality and Life." The South Atlantic Quarterly 107.1 (2008): 107-120.

Cousineau, Tom. "Pour en finir avec les rites sacrificiels." Samuel Beckett Today/Aujourd'hui 17 (2006): 221-230.

Deleuze, Gilles. Coldness and Cruelty: Masochism: Coldness and Cruelty by Gilles Deleuze / Venus in Furs by Leopold von Sacher-Masoch, Trans. Jean McNeil. New York: Zone Books, 1989.

---. Difference and Repetition, Trans. Paul Patton. London: Athlone, 1994.

---. The Logic of Sense, Trans. Mark Lester with Charles J. Stivale. London: Athlone, 1990.

Deleuze, Gilles, and Félix Guattari. Anti-Oedipus, Trans. Helen R. Lane, Robert Hurley and Mark Seem. London: Athlone, 1984.

Freedman, Ariela. Death, Men and Modernism: Trauma and Narrative in British Fiction from Hardy to Woolf. London: Routledge, 2003.

Grossman, Evelyne. "Crée-Décrée-Incréé: les défigurations de Samuel Beckett." $L a$ Défiguration: Artaud, Beckett, Michaux. Paris: Minuit, 2004. 51-80.

Heidegger, Martin. Heidegger: Basic Writings. From Being and Time (1927) to The Task of Thinking. Ed. David Farrell Krell. Revised and expanded edition. London: Routledge, 1993.

Houston Jones, David. "Néomorts et faux vivants: communautés dépeuplées chez Beckett et Agamben." Samuel Beckett Today/Aujourd'hui 17 (2006): 249-264.

Houston Jones, David. "From Contumacy to Shame: Reading Beckett's Testimonies with Agamben." Ed. Linda Ben-Zvi and Angela Moorjani. Samuel Beckett at 100: Revolving it All. 
New York: Oxford UP, 2008. 54-67.

Janvier, Ludovic. "Lieu dire." Cahier de l'Herne/Beckett. Ed. Tom Bishop and Raymond Federman. Paris: Éditions de l'Herne, 1976. 167-189.

Jung, C. G. Analytical Psychology: Its Theory and Practice: The Tavistock Lectures. London: Routledge and Kegan Paul. 1976.

Kant, Immanuel. The Critique of Judgement. Trans. James Creed Meredith. Oxford: Oxford UP, 1928.

Kantorowicz, E. The King's Two Bodies: A Study in Medieval Political Theology. Princeton: Princeton UP, 1981.

Katz, Daniel. "What Remains of Beckett: Evasion and History." Ed. Ulrika Maude and Matthew Feldman. Beckett and Phenomenology London: Continuum, 2009. 144-157.

Klossowski, Pierre. Sade My Neighbour. Trans. Alphonso Lingis. London: Quartet Books, 1992.

Kristeva, Julia. Powers of Horror: An Essay on Abjection. Trans. Leon S. Roudiez. New York: Columbia UP, 1982.

Levy, Eric. Trapped in Thought: A Study of Beckettian Mentality. Syracuse: Syracuse UP, 2007.

Madou, Jean-Pol. "The Law, the Heart: Blanchot and the Question of Community." Yale French Studies 93 (1998): 60-65.

Marvel, Laura. "The Failure of Telos in King Lear and Endgame." Ed. Anne Marie Drew. Past Crimson, Past Woe: The Shakespeare-Beckett Connection. New York: Garland, 1993. 99115.

Miller, Tyrus. "Beckett's Political Technology: Expression, Confession and Torture in the Later Drama." Samuel Beckett Today/Aujourd'hui 9 (2000): 255-278.

Myskja, Bjørn K. The Sublime in Kant and Beckett. Berlin: Walter de Gruyter, 2002.

Nancy, Jean-Luc. "Corpus." The Birth to Presence. Stanford: Stanford UP, 1993. 189-207.

Rabaté, Jean-Michel. The Ghosts of Modernity. Gainesville: U of Florida P, 1996.

Rancière, Jacques. The Flesh of Words: The Politics of Writing. Trans. Charlotte Mandell, Stanford: Stanford UP, 2004.

Scarry, Elaine. The Body in Pain: The Making and Unmaking of the World. Oxford: Oxford UP, 1985.

Shakespeare, William. King Lear. New Swan Shakespeare Advanced Series. London: Longman, 1974.

Sullivan, Victoria. "Clowns, fools, and blind men: King Lear and Waiting for Godot." Ed. Anne Marie Drew. Past Crimson, Past Woe: The Shakespeare-Beckett Connection. New York: Garland, 1993. 67-77.

Tubridy, Derval. "Words pronouncing me alive: the word-made-flesh." Samuel Beckett Today / Aujourd'hui 9 (2000): 93-104.

Weber-Caflisch, Antoinette. Chacun son dépeupleur: Sur Samuel Beckett. Paris: Minuit, 1994.

Weller, Shane. Literature and the Politics of Alterity. Basingstoke: Palgrave Macmillan, 2006.

---. "The Politics of Body Language: The Beckett Embrace." Ed. Thomas Baldwin, James Fowler and Shane Weller. The Flesh in the Text. Bern: Peter Lang, 2007. 141-159. 